\title{
The Seismic Threat to the Gibe III Dam: A Disaster in Waiting
}

\begin{abstract}
The Gibe III dam is located near the Main Ethiopian Rift (MER), the seismically active northern arm of the East African Rift (EAR), which is capable of producing large magnitude, destructive earthquakes. The United Nations Office for the Coordination of Humanitarian Affairs Regional Office for Central and East Africa estimates there is a $20 \%$ risk of 7 or 8 magnitude earthquakes occurring within the next 50 years in the MER. Earthquakes of these magnitudes pose significant threat to dams, through direct collapse or landslides triggering collapse. Collapse of the Gibe III dam would result in catastrophic loss of human life, livestock, wildlife and environments in the downstream riverine and Lake Turkana regions, exceeding the worst known dam failure in history - the Vaiont disaster in Italy. Even more moderate seismic events, combined with highly probable major landslides, sediment buildup and pressure from impounded water behind the dam threaten dam stability. The GOE discounts the seismic danger to the planned Gibe III dam, ignoring key geological information. The international development banks and bilateral agencies engaged with feasibility and impact studies as well as funding of the project—directly and indirectly—also ignore available data pointing to major seismic risk.
\end{abstract}

\section{High Seismicity in the Gibe III Dam Region}

$\gg$ The East African Rift (EAR) is a fault-bounded, long series of depressions extending about $5000 \mathrm{~km}$ from the Afar Depression in the Horn of Africa, southward through eastern Africa. For at least 40 million years, the African tectonic place has been splitting into two different plates (the Nubian and Somali). As a consequence, the rift has widened and down-dropped to form wide valleys, where rivers flow down from the bordering highlands to form lakes, including in the western and northern branches of the EAR (Fig. 3.1)—including Lakes Malawi, Victoria, Tanganyika, Albert and Turkana - the largest of eight Kenya Rift Valley lakes. This process is ongoing - contributing to the separation of the Main Ethiopian Rift (MER) portion of the EAR by 2-5 mm per year and driving the high levels of seismic activity in the tectonic province of the MER, the Afar Depression and the northern portions of the EAR eastern and western branches. An updated U.S. Geological Survey version was issued in 2014.

This tectonic province is the appropriate geographic scale for assessing earthquake probability at the Gibe III dam site. Almost all seismicity in eastern Africa is associated with these major tectonic boundaries. The abundance of recent earthquakes along the complete length of this tectonic margin demonstrates that these boundaries continue to be active zones of spreading and it is likely that large earthquakes will continue to persist along these zones (Fig. 3.2). 


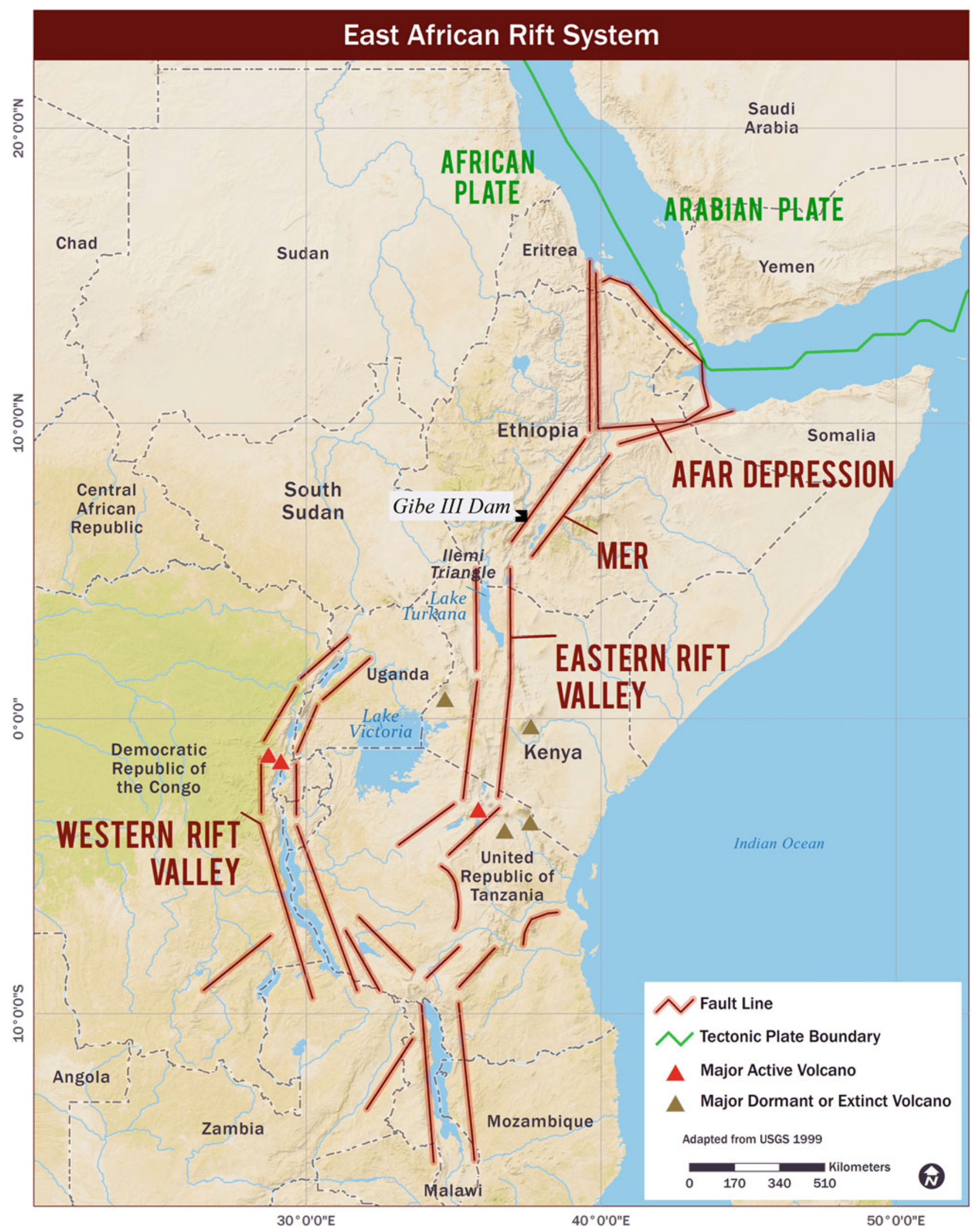

Fig. 3.1 The East Africa Rift System with Main Ethiopian Rift (MER). Source Map adapted by ARWG from U.S. Geological Survey 1999 (2012) 
OCHA Regional Office for Central and East Africa Earthquake Risk in Africa: Modified Mercalli Scale Issued: December 2007

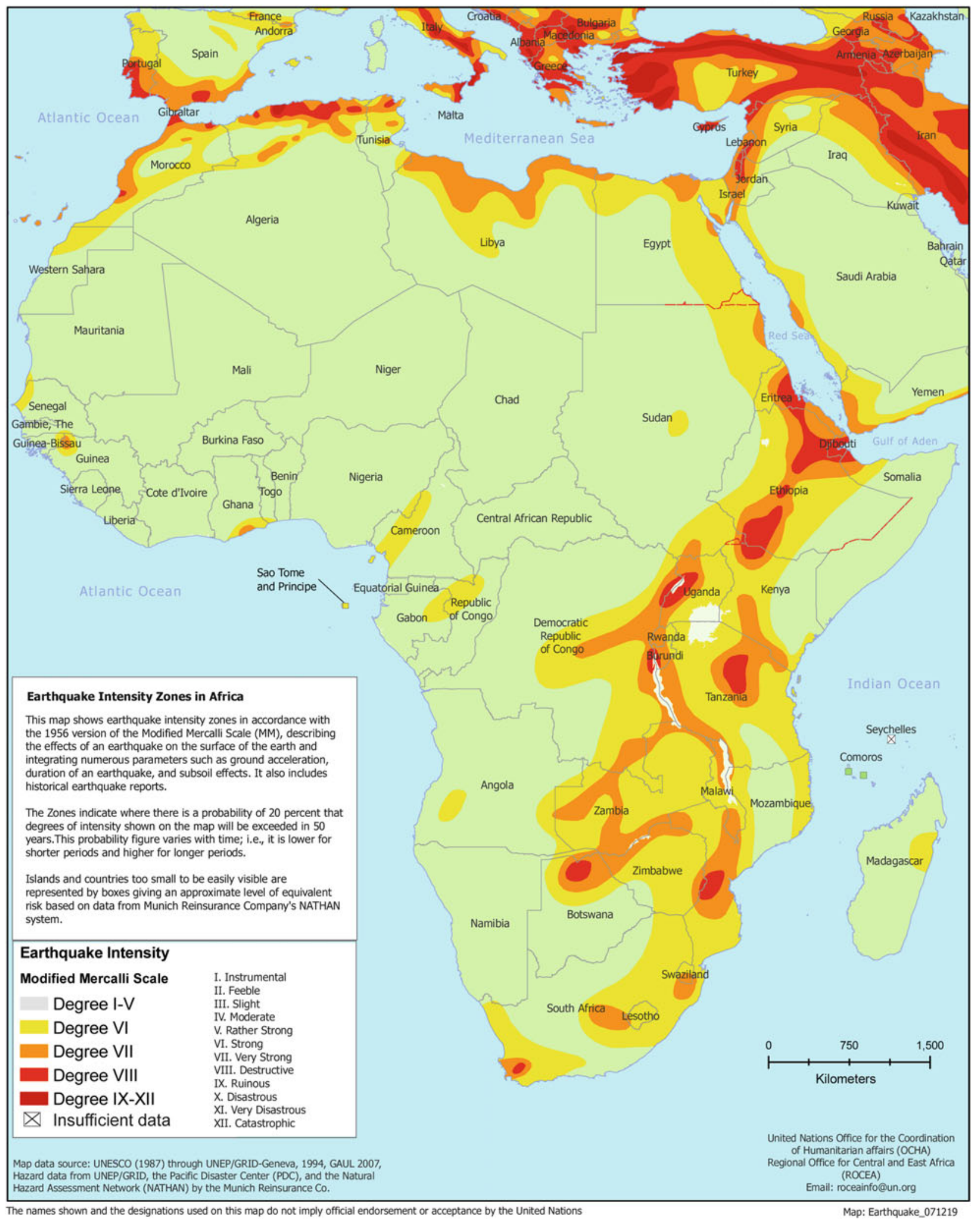

Fig. 3.2 Earthquake risk in Africa: Modified Mercalli Scale. Source U.N. OCHA-ROCEA (2007) 
$>\quad$ There is a $20 \%$ chance of at least a magnitude 7 (M7) or 8 (M8) earthquake happening within the next 50 years in the MER region, in which the Gibe III dam is located (Fig. 3.2). This estimate is based on data from the United Nations Office for the Coordination of Humanitarian Affairs Regional Office for Central and East Africa (OCHA-ROCEA) map of earthquake intensity zones (based on the 1956 Modified Mercalli Scale/MMS). No part of the MER has a predicted magnitude of less than M6 within 50 years. The OCHA report is a result of the first global earthquake assessment, and is the most comprehensive assessment of risk in the region to date.

The vicinity of the planned Gibe III dam is itself an active fault zone. Woldegabriel describes the walls of the Omo Canyon as "fault controlled". The topography is developed along a structural grain parallel to a rift that is developed along a system of faults in the area. The canyon contains several Pliocene units, including the Moiti Tuff that is $\sim 4$ Ma old and a volcanic rock of approximately the same age. Woldegabriel and Aronson (1987) describe this part of the rift system as "failed"- that is, a system partially formed but interrupted through migration.

Early cataloguing of Ethiopia's historic earthquakes reveals that large and damaging events have occurred in the Ethiopian Rift. Gouin (1979) has produced the most complete accounting. ${ }^{1}$ Records compiled by Gouin were both written and oral and covered a six-century period (through 1977), with 30 years of his own empirical observations.

Contrary to the GOE's assertion that the dam locale is not an active seismic zone of the MER, at least 10 earthquakes between 5 and 6 magnitude have occurred in the last 50 years along the MER between Addis Ababa and Lake Turkana. Six of these occurred in a single decade - the 1980s (Advanced National Seismic System, or ANSS). ${ }^{2}$ In fact, the MER is largely dominated by clusters of seismic activity rather than consistent seismic risk (Figs. 3.3 and 3.4). Examples of this include the 1906 cluster in the MER itself, including two M6 earthquakes, and the 1960 cluster of earthquakes south of Lake Langano, $150 \mathrm{~km}$ south of Addis Ababa. Regarding the 1906 earthquake swarm. Gouin identified the magnitude of the main shock as M 6.75-with a shaking intensity of M 8. He placed the epicenter 100 kilometers south of Addis Ababa-squarely within the Main Ethiopian Rift (MER). Gouin also noted a foreshock of M 6.6 and the very strong shaking intensity of 7 (ibid.). The cluster in 1906 actually included eleven separate shocks, at least four of which were greater than M6, and three of which were nearly M7s. Additionally, Gouin includes reports from witnesses near Lake Langano that placed the magnitude of the "main" quake at M9 that is, a ruinous level, should any main structures have been present. As a result of this quake, a major hot water Geyser developed on an island at the north end of Lake Langano, with two pulses a minute that produced water heights of $30 \mathrm{~m}$. The geyser continued in reduced volume and periodicity for more than 20 years. Cumulatively, fourteen earthquakes greater than M5 have occurred within $300 \mathrm{~km}$ of the GIBE III dam site during the last century (Gouin op. cit.; ANSS Database).

According to Steven Walter of the U.S. Geological Survey:

The significance of the 1906 is twofold: 1) It demonstrates that earthquakes capable of producing destructive to ruinous shaking intensities can occur within the rift zone, and 2) it demonstrates that like the Juba, Sudan swarm, areas along the rift that had been relatively quiet prior can produce large earthquakes-present activity is no guarantee of future activity, as it were. ${ }^{3}$

Even one moderate (magnitude 5 to 6) earthquake every five years in the zone of the Gibe III dam would be reason for concern, and the fact that the zone is subject to bursts of seismic activity poses an even greater risk, as there would be little time to repair damages to structures between one earthquake and the next. The cumulative impacts of these clusters would be greater than any individual M5 earthquake.

Even so-called "quiet" zones of rifts can experience large-magnitude quakes and thus cannot be trusted to remain "quiet" (Table 3.1; Figs. 3.3 and 3.4). This is evidenced by a 1990 cluster of earthquakes near Juba in South Sudan, a previously quiet rift area (Gouin op. cit.).

Investigations of the recent disasters of tunnel collapse at the Gibe II (termed GG II) project by Kinde and Engeda (2010) pointed to seismic instability as an underlying cause. The investigators stated that "the failures reported in GG II always

\footnotetext{
${ }^{1}$ Gouin was founder of the Geophysical Observatory in Addis Ababa and served as its primary seismologist until just before his 1979 book, Earthquake History of Ethiopia and the Horn of Africa.

${ }^{2}$ Advanced National Seismic System (ANSS) of the U.S. Geological Survey.

${ }^{3}$ See report in Carr (2012). Several of the public documents referenced here were introduced in Walter's report.
} 
Table 3.1 Earthquakes within $300 \mathrm{~km}$ of the Gibe III (3) dam since 1906

\begin{tabular}{|c|c|c|c|c|}
\hline Date & Magnitude (NEIC) & Magnitude (Gouin) & Distance from Gibe III $(\mathrm{km})$ & Distance from Plate boundary \\
\hline 25 Aug 1906 & & 6.6 & 185 & 35 \\
\hline 28 Oct 1906 & & $6 . ?$ & $?$ & $?$ \\
\hline 14 Jul 1960 & & 6.3 & 134 & 23 \\
\hline 23 Jan 1968 & 5.1 & 5.1 & 207 & 152 \\
\hline 2 Dec 1983 & 5.1 & & 145 & 40 \\
\hline 20 Aug 1985 & 5.4 & & 196 & 42 \\
\hline 10 Jul 1987 & 5.3 & & 89 & 11 \\
\hline 25 Oct 1987 & 5.6 & & 171 & 19 \\
\hline 28 Oct 1987 & 5.4 & & 137 & 3 \\
\hline 8 Jun 1989 & 5 & & 63 & 15 \\
\hline 13 Feb 1993 & 5 & & 274 & 11 \\
\hline 20 Jan 1995 & 5 & & 130 & 17 \\
\hline 19 Dec 2011 & 5.1 & & 95 & 59 \\
\hline
\end{tabular}

Sources Gouin (1979), Advanced National Seismic System (ANSS) database, Walter (in Carr 2012)

occurred near faults - even when no seismic event occurred, further highlighting the dangers these projects face in actual seismic events" (Kinde and Engeda 2010). Their report continued with the conclusion:

[T]the region around the project area has a recorded history of significant seismic events. The outcome of our study shows that projects such as GGII, GGIII, and GG IV should consider seismicity into the design and construction processes. Neglecting the risks posed by seismic hazards in such a region with [sic], we believe, has tremendous negative consequences in the future usefulness of these projects. [Emphasis added.]

\section{Reservoir Seepage and Landslide Danger at the Gibe III Dam}

$>$ According to geologists working in the dam region for several decades, reservoir filling is likely to extend for years, due to heavily fractured volcanic rock throughout the Gibe III dam site, including in the reservoir's natural walls. Woldegabriel and Aronson (1987) also document these fractures for the region. Basalts, particularly those from volcanic flows that cooled unevenly, can form both vertical fractures (vesticules) and large-scale lava tubes capable of transporting large volumes of water. Basalt is especially vesiculated and highly fractured at the top and bottom of individual flows, where cooling occurs more quickly. These factors can make basalts highly permeable - some of the most productive aquifers there are- "even akin to karst". (ARWG geologist, personal communication).

Basalts dominate the geology of the MER. This is due to three dominant eras of volcanic activity: the first during the Eocene, 35-45 Ma ago; the second a series of flood basalts erupting 29-31 Ma ago; and the third, more recent shield volcanic eruptions of more alkaline basalt. The basalts that dominate the MER are composed of transitional tholeiites, are more alkalic and contain more sodium than potassium (Rogers 2005).

$\triangleright$ Even if the roller compacted concrete (RCC) construction of the proposed Gibe III performs well-a challengeable assertion - the fractured and jointed volcanic rock at the dam location would produce seepage conduits. Ongoing seismic activity will likely open up more fractures over time, so seepage from the fractured rocks in the reservoir's walls would likely slow down filling and early retention of waters in the reservoir by multiple years, according to ARWG geologists. This is especially true because of the high hydrostatic pressure from impounded water behind the dam that will promote reservoir seepage.

The resultant extended period of radically decreased river flow below the dam - already a disastrous situation from even the "up to 3 year" reservoir filling period predicted by the GOE and accepted in the AFDB's 2010 assessment-would be disastrous for indigenous communities downstream along the Omo River and around Lake Turkana. This major reduction in 


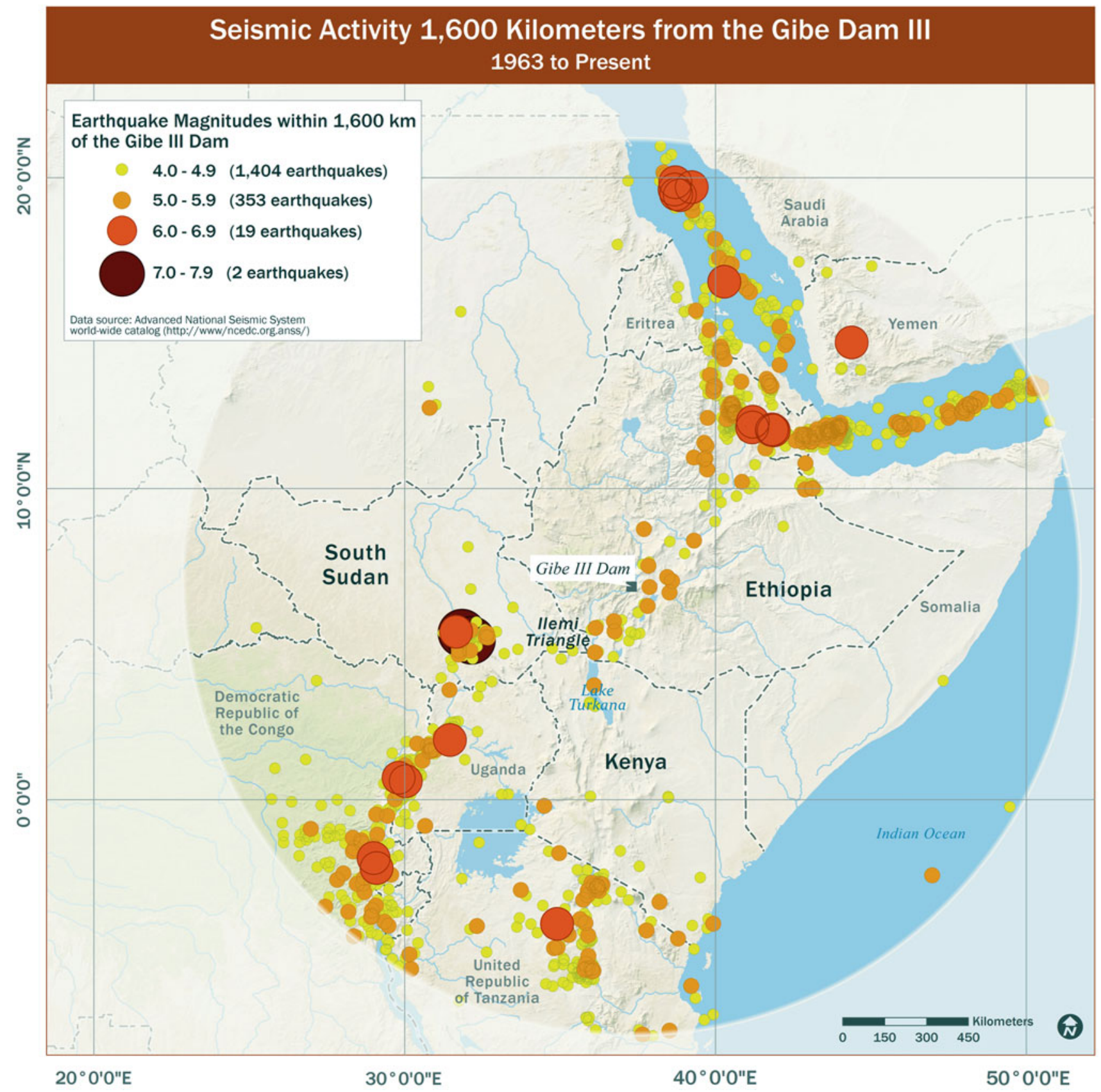

Fig. 3.3 Seismic activity within $1600 \mathrm{~km}$ of the Gibe III dam: 1963 to present. Indicated by magnitude of earthquake. Source data from the Advanced National Seismic System (ANSS) World Wide Catalogue (U.S. Geological Survey). Graphic by ARWG

Omo River downstream flow due to the Gibe III dam is greatly magnified by the radical abstraction of Omo River waters by major irrigated agribusiness enterprises the GOE is promoting throughout much of the lower Omo basin (Human Rights Watch 2012).

Even if the dam itself remains intact after a seismic event, it is highly plausible that springs, leaks and seepage developing in the adjacent rock abutments could cause a dam failure. This danger stands despite the design of the Gibe III dam calling for 'grouting fractures' within the native rock around the dam. 


\section{Seismic Activity 700 Kilometers from the Gibe Dam III 1906 to Present}

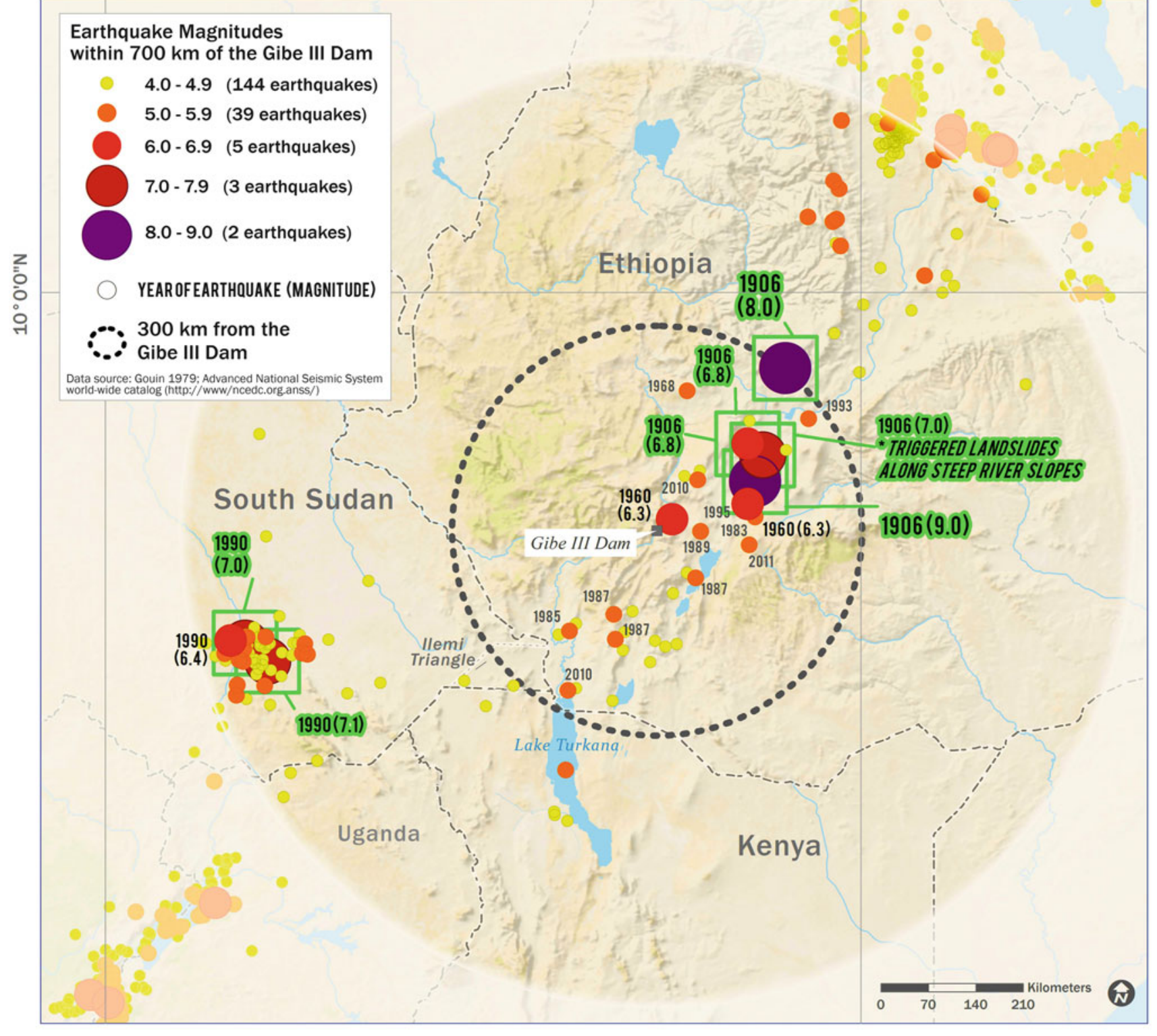

$30^{\circ} 0^{\prime} 0^{\prime \prime} \mathrm{E}$

$40^{\circ} \mathrm{O}^{\prime} \mathrm{O}^{\prime \prime} \mathrm{E}$

Fig. 3.4 Seismic activity within $700 \mathrm{~km}$ of the Gibe III dam: 1906 to present. Indicated by magnitude of earthquake. Source data from Gouin (1979), Advanced National Seismic System (ANSS), World Wide Catalogue (U.S. Geological Survey). Graphic by ARWG

$>$ Hot springs occur within the Lower Omo basin region and these are most likely generated by deep circulation along faults. The well known 'forty springs' of Arba Minch result from fractures in volcanic rocks contiguous with those at the proposed dam site. These hot springs are most likely generated by deep circulation along faults. Similar springs have been documented in the Ugandan portion of the rift valley as caused by extremely high filtration of rainfall in the mountains through basaltic fractures to the base of the mountains.

$\triangleright$ Filling of the reservoir and early dam operation would promote the probability of a major landslide, particularly as within the context of the inherent instability of the steep, highly fractured 'natural walls' of the reservoir. Impoundment at Gibe III will change the base level of the river in the immediate area: local aquifers are fracture controlled, 
and it is possible that some slip surfaces (landslide soles) may become lubricated so that rock masses are more likely to slide. Saturation of clay-rich soils along the canyons exacerbates the risk of swelling and landslides, as well.

Landslides in artificial reservoirs can be triggered by the buoyancy of permeable layers of rock in the surrounding slopes, and by structural breaks between geologic layers in those slopes, particularly when divided by thin layers of clay or other potentially lubricating material.

The high probability of landslides, along with highly likely buildup of sediment behind the Gibe III dam - even with mild to moderate earthquake occurrence, let alone a major seismic event—presents a risk to the dam's integrity. Sedimentation is promoted, for example, by soil erosion upstream — exacerbated by deforestation and overexploitation of soils for agriculture.

As was evident with the Vaiont landslide dam disaster in northern Italy in 1963, initial geologic testing of the slopes surrounding the reservoir did not find evidence of potential problems because the clay layer between the top geologic layers of the dolomites was only $\sim 1 \mathrm{~mm}$ thick in many places. The Vaiont event is discussed in detail by Semenza and Ghirotti (2000), Genevois and Ghirotti (2005), and Massironi et al. (2013).

The 1963 disaster of Vaiont illustrates the significance of dam failure.

In Vaiont, more than 2600 people were killed when 260 million cubic meters of a slide block moved suddenly into the newly filled Vaiont Reservoir - behind a very tall dam that blocked a deep valley. The intensive landslide occurred within seconds and displaced more than half of the reservoir's water, generating a giant wave that reached a height of 250 meters which then created an enormous wall of water that swept into nearby villages and towns, destroying everything in its path. The dam itself remained intact. In the Vaiont case, the rockslide and ensuing flood could have been readily foreseen by logical consulting. The cause of the landslide may also be pertinent to a consideration of the Omo situation. The sedimentary rocks of the Vaiont River Valley include layers of shale, a clay-rich rock. And the rocks comprising the nearby mountain (Mt. Toc) tilt steeply toward the reservoir. When the dam was finished in 1960, filling of the reservoir introduced groundwater into the shale layers, causing them to swell and become unstable. At first, the mountainside began slowly creeping down slope at a rate of half an inch per week. As filling continued and more groundwater seeped into the mountain, the rate of slippage increased to eight inches per day, and ultimately to 30 inches per day, just before the 1963 disaster. [ARWG earth scientist, personal communication]

$>$ Gibe III dam failure would be catastrophic for the Ethiopian and Kenyan populations in the entire downstream Omo basin and Lake Turkana region: tens of thousands of people would be obliterated and hundreds of thousands more could face calamity. The essentially permanent destruction of livestock and environmental resources in both nations from such an event is of such magnitude as to be inestimable.

\section{Failed Government and Development Bank Seismic Review}

$>$ The seismic threat, along with the related dangers of landslides, sediment buildup and seepage are entirely discounted by the GOE in both of its major impact assessments (GOE 2009a, b). By adopting this approach, including with omission of available information and Literature, the GOE ignores the implications of such threat for its own indigenous citizens living downstream from the Gibe III dam, along with the vast indigenous Kenyan population residing along Lake Turkana.

The government's approach to the seismicity threat is 'bolstered' by a belated and dismissive seismicity report prepared by the contractor for the dam's construction-Salini (see last chapter). Salini's report remains unchallenged by the development banks although they are fundamental contributors to the long-term planning, financing and rationalizing of the Gibe III and/or its linked developments.

The GOE's impact assessments for the Gibe III refer to a GOE Seismic Hazard Assessment (2007) that considers seismic events only during the past century (GOE 2009b). They conclude that there is "no real evidence" of present seismic activity in the project area. 
- The project area (East-North East quaternary trending) does not seem to be active at this time, as illustrated in detail in the above-mentioned report.

- Despite the evidences that a certain seismic activity affected the region in historical times, according to the L1D Geological Report no evidences seem to exist of present seismic activity in the project area (GOE 2009a).

As evidenced above, both the GOE timeframe and geographic scale are far too narrow to effectively determine seismic risk. Section 5.13 of the GOE's assessment, by noting only earthquake occurrences within the recorded time, clearly implies that this narrow window of time is indicative of the (lack) of potential for future earthquake activity. Typical seismic design, however, looks much further back in time to faults showing activity.

The appropriate geographic zone for assessing seismic risk in the Gibe III region is misrepresented in the GOE reports. Citing the International Commission on Large Dam's (ICOLD) guidelines for determining seismic risk, the GOE nevertheless ignores ICOLD's guideline that the tectonic province as a whole be considered when evaluating probabilities of tectonically linked seismic risk. As noted above, the tectonic province for this region should include the northern portion of the East African Rift Valley, including the northern ends of the Western and Eastern branches of the rift valley, the Main Ethiopian Rift, and the Afar Depression. These systems are linked, tectonically, and thus should be considered when evaluating seismic probabilities.

The suggestion in the downstream GOE impact assessment (GOE 2009b) for a 'warning system' with scattered sirens throughout the riverine zone downstream from the Gibe III dam, in order to warn of 'necessary releases' of flood pulses from the dam - or imminent dam failure - is nonsensical in the extreme. The area of impact of a major water 'release', dam overtopping or dam failure - one encompassing both the lower Omo basin and the Lake Turkana region - is so massive, with hundreds of thousands of agropastoralists, pastoralists and fishers confined to Omo riverside/delta lands, or the level plains around Lake Turkana, that such a warning system would be useless. Additionally, historically, these systems have rarely been implemented for other large dams, and sudden releases of water due to impending reservoir overtopping have often resulted in downstream drownings (for example, Cahorra Bassa in Mozambique).

Such an event would send enough water, sediment, and (in the case of dam collapse) material from the dam itself, into a massive wave, or series of waves through the lowermost Omo basin and into Lake Turkana - destroying human communities and biological systems in its path. These matters are essentially discounted in the European Investment Bank and both African Development Bank impact assessments $(2009,2010)$. The EIB (2010) report is dismissive of the seismic threat and responded to Africa Resources Working Group (2009) evidence summarized (in 2009) only with the statement, "Some risk is unavoidable." The AFDB (2010) impact assessment for Gibe III impacts on Lake Turkana offers only inconspicuous notation that a dam collapse would produce a two meter rise in lake level in the body of the text - omitting any reference to the cataclysmic force and impact of such an event and excluding the subject altogether in the assessment's Summary and Conclusions.

\section{Literature Cited}

Advanced National Seismic System (ANSS) World Wide Catalogue (U.S. Geological Survey).

Africa Resources Working Group (ARWG). 2009. In A commentary on the environmental, socioeconomic and human rights impacts of the proposed Gibe III Dam in the lower Omo River Basin of Southwest Ethiopia. http://www.arwg-gibe.

African Development Bank (AFDB). 2009. In Eds. A.S. Kaijage, N.M. Nyagah, Final Draft Report, Socio-economic analysis and public consultation of Lake Turkana Communities in Northern Kenya. Tunis, 189 pp.

African Development Bank (AFDB). 2010. In Ed. S. Avery, Assessment of hydrological impacts of Ethiopia's Omo Basin on Kenya's Lake Turkana water levels, Final Report, 146 pp.

Carr, C.J. 2012. Humanitarian catastrophe and regional armed conflict brewing in the border region of Ethiopia, Kenya and South Sudan: The proposed Gibe III Dam in Ethiopia, Africa Resources Working Group (ARWG), 250 pp. https://www.academia.edu/8385749/Carr_ARWG_ Gibe_III_Dam_Report.

Ethiopia, Government of (GOE), Ethiopian Electric Power Corporation (EEPCO). 2009a. CESI, Mid-Day International Consulting Engineers (MDI), Gibe III Hydroelectric Project, Environmental and social impact assessment, Report No. 300 ENV RC 002C Plan.

Ethiopia, Government of (GOE), Ethiopian Electric Power Corporation (EEPCO), Ethiopian Electric Power Corporation (EEPCO). 2009b. Agriconsulting S.P.A., Mid-Day International Consulting, Level 1 Design, Environmental and social impact assessment, additional study of downstream impacts. Report No. 300 ENV RAG 003B.

European Investment Bank (EIB). 2010. Sogreah Consultants, Independent review and studies regarding the environmental and social impact assessments for the Gibe III hydropower project, Final Report, $183 \mathrm{pp}$.

Genevois, R., and M. Ghirotti. 2005. The 1963 Vaiont landslide. Giornale di Geologia Applicata 1: 41-52.

Gouin, P. 1979. Earthquake history of Ethiopia and the Horn of Africa. Ottawa: International Development Research Center. 
Human Rights Watch. 2012. What will happen if hunger comes? Abuses against the Indigenous Peoples of Ethiopia's Lower Omo Valley. http:// www.hrw.org/sites/default/files/reports/ethiopia0612webwcover.pdf.

Kinde, S, and S. Engeda. 2010. Fixing Gibe II_Engineer's perspective. http://www.digitaladdis.com/sk/Fixing_Gilgel_Gibe_II.pdf.

Massironi, M. et al. 2013. Geological Structures of the Vajont Landslide. Italian Journal of Engineering Geology and Environment. Presented at International Conference, Vaiont 1963-2013, October 8-10, Padua, Italy.

Rogers, N.W. 2005. Basaltic magmatism and the geodynamics of the East African Rift System. Geological Society London, Special Publications 259(1):77-93.

Semenza, E., and M. Ghirotti. 2000. History of the 1963 Vaiont slide: the importance of geological factors. Bulletin of Engineering Geology and the Environment 59: 87-97.

United Nations, Office for the Coordination of Humanitarian Affairs Regional Office for Central and East Africa (OCHA-ROCEA). 2007. Earthquake risk in Africa.

U.S. Geological Survey. Walter, S. 2012. Gibe 3 Seismicity review. Report prepared for C. J. Carr

U.S. Geological Survey. Hayes, G.P. et al. 2014. Seismicity of the Earth 1900-2013 East African Rift: U.S. Geological Survey Open-File Report 2010-1083-P, 1 sheet, scale 1:8,500,000, http://dx.doi.org/10.3133/of20101083p.

Woldegabriel, G., and J.L. Aronson. 1987. Chow Bahir Rift, a failed rift in Southern Ethiopia. Geology 15: 430-433.

Open Access This chapter is distributed under the terms of the Creative Commons Attribution-NonCommercial 2.5 International License (http:// creativecommons.org/licenses/by-nc/2.5/), which permits any noncommercial use, duplication, adaptation, distribution and reproduction in any medium or format, as long as you give appropriate credit to the original author(s) and the source, provide a link to the Creative Commons license and indicate if changes were made.

The images or other third party material in this chapter are included in the work's Creative Commons license, unless indicated otherwise in the credit line; if such material is not included in the work's Creative Commons license and the respective action is not permitted by statutory regulation, users will need to obtain permission from the license holder to duplicate, adapt or reproduce the material. 